\title{
The economic burden of coronavirus disease 2019 (COVID-19): evidence from Iran
}

\author{
Mohsen Ghaffari Darab ${ }^{1}$, Khosro Keshavarz ${ }^{2}$, Elnaz Sadeghi ${ }^{3}$, Javad Shahmohamadi ${ }^{4}$ and Zahra Kavosi ${ }^{2^{*}}$ (D)
}

\begin{abstract}
This study aimed to estimate both direct medical and indirect costs of treating the Coronavirus disease 2019 (COVID-19) from a societal perspective in the patients at a referral hospital in Fars province as well as the economic burden of COVID-19 in Iran in 2020.
\end{abstract}

Methods: This study is a partial economic evaluation and a cross-sectional cost-description study conducted based on the data of the COVID-19 patients referred to a referral university hospital in Fars province between March and July 2020. The data were collected by examining the patients' records and accounting information systems. The subjects included all the inpatients with COVID-19 (477 individuals) who admitted to the medical centre during the 4 months. Bottom-up costing (also called micro-costing approach), incidence-based and income-based human capital approaches were used as the main methodological features of this study.

Results: The direct medical costs were estimated to be $28,240,025,968$ Rials $(\$ 1,791,172)$ in total with mean cost of $59,203,409$ Rials ( $\$ 3755)$ per person (SD $=4684 \$ / 73,855,161$ Rials) in which significant part (41\%) was that of intensive and general care beds $(11,596,217,487$ Rials equal to $\$ 735,510(M=24,310,728$ Rials or $\$ 1542, S D=34$, 184,949 Rials or $\$ 2168$ (. The second to which were the costs of medicines and medical consumables (28\%). The mean indirect costs, including income loss due to premature death, economic production loss due to hospitalization and job absenteeism during recovery course were estimated to be $129,870,974$ Rials $(\$ 11,634)$ per person. Furthermore, the economic burden of the disease in the country for inpatient cases with the definitive diagnosis was 22,688,925,933,095 Rials equal to \$1,439,083,784.

Conclusion: The results of this study showed that the severe status of the disease would bring about the extremely high cost of illness in this case. It is estimated that the high prevalence rate of COVID-19 has been imposing a heavy economic burden on the country and health system directly that may result in rationing or painful cost-control approaches.

Keywords: COVID-19, Coronavirus, Economic burden, Health policy, Hospital costs, Intensive care units, Cost-ofillness, Iran

\footnotetext{
*Correspondence: kavosiz@sums.ac.ir; zhr.kavosi@gmail.com

${ }^{2}$ Health Human Resources Research Centre, School of Management and Medical Informatics, Shiraz University of Medical Sciences, Shiraz, Iran

Full list of author information is available at the end of the article
} 


\section{Background}

The novel coronavirus disease, currently known as Coronavirus disease 2019 or simply COVID-19 (caused by the SARS-CoV-2 pathogen), was first introduced as an epidemic in December 2019 in Wuhan, Hubei, China [1, $2]$. It was increasingly spread in many countries on all five continents of the world, with the World Health Organization (WHO) announcing in March 2020 that the COVID-19 pandemic was one of the health issues raising international concern [3]. The WHO also called for early diagnosis, isolation and treatment of the patients, contact tracing, and social distancing in order to break the chain of virus transmission [4].

According to the statistics published on the worldometers database, more than $16,433,715$ million people in the world had been infected with COVID-19 by July 2020 , of whom over 652,454 individuals have lost their lives. The information of this database also showed 291, 172 and 15,700 for these two figures about Iran, respectively [5]. Transmission of the virus through respiratory droplets has caused the disease to spread rapidly and infect many people [6]. Individuals with a mean age of 55.5 years [7] and those with underlying conditions, such as hypertension, diabetes, and heart disease, are at a higher risk $[8,9]$. Thus, the health status of the elderly and those with underlying illnesses are twice as much important because demand aggregation followed by the collapse of the health system may prevent the provision of routine medical services to the people in need. For example, modelling studies by the World Health Organization showed that stopping the provision of antiretroviral therapy services in the Sub-Saharan could lead to an additional 500,000 AIDS-related deaths [10, 11].

From an economic perspective, the spread of COVID19 , the ever-increasing number of patients, and the complications of the disease have imposed high direct medical and indirect costs on patients, the health system and the government [12]. As far as the economic burden of direct medical costs is concerned, although the costs vary with the number of the infected people, the severity of the disease, mean length of stay in the hospital, mean length of stay in the ICU, and other factors [13, 14], international studies showed that medical costs of the patients with COVID-19 were significantly higher than those of other infectious diseases due to the higher probability of hospitalization and mortality [15]. These circumstances are also right about the need for COVID-19 patients for special care services and the related costs [16-18]. Statistics have shown that $3 \%$ of the people with COVID-19 in the world are in critical condition and need special care services [5]. The results of a study on 138 individuals with COVID-19 in Wuhan, China, indicated that $26.1 \%$ of the patients used special care services, of whom 41.6 and $47.2 \%$ received non-invasive and invasive ventilation, respectively [19]. In Lombardy, Italy, $88 \%$ of the patients admitted to the ICU received invasive ventilation, and $11 \%$ received non-invasive one [20]. The daily cost of hospitalization in the ICU is generally 3-4 times higher than in general wards [21].

Moreover, the lost income due to the disease or mandatory stay at home or the death of the workforce due to the disease could be considered as indirect costs [22-24]. The prevalence of COVID-19 and closure of many industries would reduce Gross Domestic Product (GDP) $[25,26]$. According to studies, the global spread of the disease will lead to a decrease in global GDP by 2.5-3\% per month [27]. Furthermore, the outbreak of COVID-19 severely damaged the world's top fifteen economies [28]. Comparing the economic effects of this disease with those of past epidemics shows that the economic crisis facing the world is much more severe than what was experienced in the past.

Therefore, regarding the high costs of the treatment of the patients with COVID-19 and its resulting economic burden on the health system and the country generally, and due to the impending economic crisis, it seems crucial to calculate direct medical and indirect costs of treatment of the disease.

\section{Methods}

This applied research is a partial economic evaluation and a cross-sectional cost-description study. The research population consisted of all the patients with COVID-19 who had referred to a primary referral medical centre for COVID-19 patients in Fars province, Iran, by July 2020 . As the research sample was equal to the research population, no sampling was done, and all the patients were examined through a census.

This included cost and demographic information of all confirmed cases undergoing the treatment processes from diagnosis to discharge at the Hospital. The patients whose part of the treatment process had been performed outside the hospital and were referred to other hospitals or a rehabilitation centre were excluded from the study. The required data were collected through the forms designed in two sections: the patient's demographic information and characteristics, and cost information. Given that the present study was conducted from the society perspective, the costs included direct medical (DC) and indirect costs (IC). Based on a set of measures, public policies and health protocols related to unprecedented circumstances of disease control and prevention in the time of COVID-19, people have been encouraged to keep physical and social distance and avoided having unnecessary social contacts, we restricted the direct cost estimation to medical cost only. In other words, there were little possibilities for interviewing patients in order to gather relevant information. It was going to put 
people at a lower risk of illness. Further, there was no access to an alternative source of information to collect such data.

The bottom-up costing method was used to calculate direct medical costs due to the lack of a proper and accurate database. The bottom-up methodology uses comprehensive information on procedure circumstances and input utilization data from reports (or observed usage) related to each patient at the service provider level to calculate cost per unit. Indeed, it is based on collecting all individual data of consumption of resources and then aggregating all individual costs, summing them to achieve the total costs. Although bottom-up approach might be more time-consuming, it is comparatively more accurate as well [29].

The incidence approach was also used to provide cost information [30]. There may be little difference between the prevalence and incidence approach in this study, significantly, given that COVID-19 is an emergent disease which there have not been longterm sequelae associated with it yet. However, since this approach is more practical in the case where it will help policy-makers to develop preventive measures and while we included patients from the onset of this epidemy in Iran, it seems that this term properly matches to the methods here [31]. The solution to incidence is based on the idea that a stream of health-related expenses should be allocated to the year in which the stream begins. Thus the approach to incidence allocates all direct, morbidity and mortality costs based on their present-value and to the year in which the disease first appears [32, 33].

\section{Calculation of direct medical costs}

In this study, the calculation of direct medical costs conducted based on electronic medical data through the hospital information system (HIS). The data, subsequently, were classified into nine categories as follows: the costs of intensive and ordinary bed services, physician visit cost_ in Iran's health system cost of the visit includes the fee that is paid for each time a physician a patient at their bedside to examine or prescribe them_, counselling, nursing services, drugs and medical consumables, rehabilitation, dialysis, imaging, electrography, laboratory, and other services (including monitoring in non-intensive care units, compilation and prescription of therapeutic diets, cannula implantation for venous-venous-hemodialysis, blood and blood products transfusion, tracheal intubation, level-one critical care or triage, blood oximetry or continuous pulse oximetry, temporary catheter insertion into the bladder, and cold room). The average total direct medical costs of each patient with
COVID-19 were calculated as the sum of the average inpatient cost in each category:

Total direct medical cost per patient $=$ (the mean cost of counselling) + (the mean cost of nursing services) + (the mean cost of medicine and medical consumables) + (the mean cost of rehabilitation) + (the mean cost of dialysis) + (the mean cost of imaging) + (the mean cost of electrography) + (the mean cost of laboratory) + (the mean cost of other items)

Regarding the significance of investigating the cost difference between the inpatient care for severe cases needing care in ICU or otherwise, direct medical cost for those patients was calculated and reported separately. This also is able to demonstrate the variability among the quantities. Service Charges used in calculation and estimations of this study all are based on official prices which had been approved by health authorities at the national level.

\section{Calculation of indirect costs}

In this study, the indirect costs were also investigated based on the income-based human capital approach and measured in two parts, including the wages that a patient loses due to absenteeism (hospitalization or home rehabilitation) and the productivity loss as a result of a patient's premature death at the ages of 15 to 65 . The lost productivity was considered zero for the individuals under the age of 15 and over 65 who were not economically productive.

The Forgone Labor Output (FLO) equation was used to calculate the potential economic production loss due to the premature deaths:

$$
\mathrm{P}_{1}=\sum_{i=1}^{N} \frac{W *(1+g)^{i}}{(1+r)^{i}}
$$

In this equation, $P_{1}$ is the current value of the predicted future income per workforce, $\mathrm{N}$ is the mean working years per person at the age of $\mathrm{i}$, W shows the mean current income per person, $r$ stands for the social discount rate, and $g$ is the annual real income growth rate per person [34].

Economic Burden:

\section{Total cost (direct medical cost + indirect $\cos t)$ $\times$ estimated number of infected inpatient cases in}

In order to estimate the total economic burden on the country, the total cost (total direct medical and indirect costs) for each patient was first calculated and then multiplied by the total number of cases with COVID-19 throughout the country [35].

Since the available data suggested that the disease lasted for an acute episode and less than 30 days, the discount rate was not applied; in addition, all the costs were calculated based on purchasing power 
parity (PPP) 2020, adjusted by, equivalent to 15,766 Rials per 1 dollar [36].

\section{Results}

\section{Epidemiological finding}

Of the 477 patients studied, none of the patients was under 15 years old, $41 \%$ were $15-45$ years old, $38 \%$ were $45-65$, and $21 \%$ were 65 years or more; Among them, $56 \%$ were male, and $44 \%$ were female.

(Table 1: Table 1: Demographic and Disease Severity Information of the Patients). Fever, muscle pain, cough and respiratory distress were the main signs and symptoms among the patients. Nearly half of the patients suffered from at least one of the underlying diseases diabetes, heart disease or hypertension. Oxygen saturation levels were below $93 \%$ in $41 \%$ of the patients. $4 \%$ received tracheal intubation. Moreover, $7 \%$ of the patients received ICU care due to a severe form of the disease.

\section{Direct medical costs}

According to the results, the total direct medical costs were estimated to be $28,240,025,968$ Rials $(\$ 1,791,172)$, in which the intensive and general care beds expenses were the largest share of costs (41\%) with 11,596,217,487 Rials equals to $\$ 735,510$. Following that, the main costs were those of medicines and medical consumables $(28 \%)$ with $8,044,070,257$ Rials equals to $\$ 510,209$ physician visits costs (12\%) 3,422,848,975 Rials equal to $\$ 217,100$, and electrography and laboratory (9\%) 2,645,752,049 Rials equal to $\$ 167,811$. Nursing and consulting services each one accounted for merely $2 \%$ of total costs (Table 2: Medical Direct and Indirect Costs of studied patients).

\section{Indirect costs}

\section{Productivity loss due to job absenteeism}

Of the patients treated, $6.5 \%$ died; of these, $4 \%$ were in productivity age, who died an average of 11 years before age 65. The results showed that the mean length of hospital stay for each COVID-19 patient was 7 days on

Table 1 Demographic and Disease Severity Information of the Patients

\begin{tabular}{llll}
\hline Gender & Variable & Total number & \% \\
& Male & $\mathbf{2 6 6}$ & $\mathbf{5 6}$ \\
& Female & $\mathbf{2 1 1}$ & $\mathbf{4 4}$ \\
\hline Age Groups & $0-15$ & 0 & 0 \\
& $15-45$ & 197 & 41 \\
& $45-65$ & 180 & 38 \\
& +65 & 100 & 21 \\
Severe Cases & (ICU patients) & 36 & 7 \\
(ICU patients) & & & \\
\hline
\end{tabular}

average $(\max =38, \min =2)$ (this figure for sever cases was 11 days on average with max and min of 38 and 2, respectively); concerning this, the total lost income of a COVID-19 patient at the age of 15-65 due to hospitalization was estimated to be 5,950,524 Rials (equal to \$ 378) (According to the data of the Statistical Centre of Iran, the minimum monthly wage in 2019 was $24,000,000$ Rials, equal to the daily income of 800,000 Rials per individual).

Also, based on the epidemiological data, a patient's lost income due to absenteeism during the recovery period of 21 days was estimated to be $16,800,000$ Rials (equal to \$ 1065) (Table 2: Medical Direct and Indirect Costs of studied patients).

\section{Production loss due to premature death}

Estimation of Potential Production Loss due to premature death followed a methodology previously described based on the Forgone Labor Output equation (section 2: Method). Regarding this, average lost years was calculated 11 years based on deducing the age at death from expected working age (65 years) in patients between 15 and 65 years of age. Due to the lack of detailed wage information, the minimum annual wage was considered as the average income per capita in 2020 equal to 288,000,000 Rials (based on information from the ministry of cooperative labour and social welfare), and the annual growth rate for real income per capita (g) was considered $3 \%$. The discount rate also was set at $6 \%$. Finally, the economic loss caused by every premature death from COVID-19 estimated to be $2,677,698,726$ Rials (equal to $\$ 169,838$ ).

$$
\mathrm{P}_{1}=\sum_{i=1}^{11} \frac{288,000,000 *(1+0.03)^{i}}{(1+0.06)^{i}}=2,677,698,726 \text { Rials }
$$

According to the mortality rate among hospitalized cases derived from the study, only $4 \%$ of this amount $(129,870,974$ Rials equal to $\$ 11,634)$ was considered in the calculation of the average indirect costs per inpatient.

Economic burden imposed on all inpatients with COVID-19 in Iran estimated to be 22,688,925,933,095 Rials equal to $\$ 1,439,083,784$ in the country based on the number of all inpatient cases equal to 120,000 individuals up until the end of July and the average cost of disease;

\section{Discussion}

This study was the first study on the cost of illness among COVID-19 patients in Iran. The outbreak of the COVID-19 and the increasing number of patients in Iran imposed high costs on the infected people and the health system. The economic burden of the disease in addition to the economic crisis facing the country certainly due to economic sanctions imposed on Iran by 
Table 2 Indirect and Direct Medical Costs of studied patients

\begin{tabular}{|c|c|c|c|c|c|c|c|c|}
\hline $\begin{array}{l}\text { Direct Medical } \\
\text { Cost }\end{array}$ & $\%$ & $\begin{array}{l}\text { Total cost all } \\
\text { patients }\end{array}$ & $\begin{array}{l}\text { Mean cost } \\
\text { per patient }\end{array}$ & SD & $\begin{array}{l}\text { Mean Cost Per } \\
\text { non-sever patient }\end{array}$ & SD & $\begin{array}{l}\text { Mean Cost Per } \\
\text { ICU patient }\end{array}$ & SD \\
\hline $\begin{array}{l}\text { General and } \\
\text { Intensive Care } \\
\text { Beds }\end{array}$ & 41 & $\begin{array}{l}11,596,217,487(\mathrm{IR}) \\
735,510(\$)\end{array}$ & $\begin{array}{l}24,310,728(\mathrm{IR}) \\
1542(\$)\end{array}$ & $\begin{array}{l}34,184,949(\mathrm{IR}) \\
2168(\$)\end{array}$ & $\begin{array}{l}\text { 18,466,239 (IR) } 1171 \\
(\$)\end{array}$ & $\begin{array}{l}18,490,652(\mathrm{IR}) \\
1173(\$)\end{array}$ & $\begin{array}{l}95,905,725(\mathrm{IR}) \\
6083(\$)\end{array}$ & $\begin{array}{l}69,111,570(\mathrm{IR}) \\
4384 \text { (\$) }\end{array}$ \\
\hline $\begin{array}{l}\text { Physician Visit } \\
\text { Costs }\end{array}$ & 12 & $\begin{array}{l}3,422,848,975(\mathrm{IR}) \\
217,100(\$)\end{array}$ & $\begin{array}{l}7,175,784(\mathrm{IR}) \\
455(\$)\end{array}$ & $\begin{array}{l}3,810,035(\mathrm{IR}) \\
242(\$)\end{array}$ & 7,037,094(IR) 446 (\$) & $\begin{array}{l}3,465,158(\mathrm{IR}) \\
220(\$)\end{array}$ & $\begin{array}{l}8,874,734(\mathrm{IR}) \\
563(\$)\end{array}$ & $\begin{array}{l}6,422,523(\mathrm{IR}) \\
407(\mathbf{\$})\end{array}$ \\
\hline $\begin{array}{l}\text { Consultant and } \\
\text { surgeon }\end{array}$ & 2 & $\begin{array}{l}544,642,687 \text { (IR) 34, } \\
545(\$)\end{array}$ & $\begin{array}{l}1,141,809(\mathrm{IR}) \\
72(\$)\end{array}$ & $\begin{array}{l}1,469,135(\mathrm{IR}) \\
93(\$)\end{array}$ & $940,031(\mathrm{IR}) 60(\$)$ & $\begin{array}{l}1,138,595(\mathrm{IR}) \\
72(\$)\end{array}$ & $\begin{array}{l}3,613,588(\mathrm{IR}) \\
229(\$)\end{array}$ & $\begin{array}{l}2,218,364(\mathrm{IR}) \\
141 \text { (\$) }\end{array}$ \\
\hline Nursing services & 2 & $\begin{array}{l}597,734,159 \text { (IR) 37, } \\
912(\$)\end{array}$ & $\begin{array}{l}1,253,111(\mathrm{IR}) \\
79(\$)\end{array}$ & $\begin{array}{l}1,449,037(\mathrm{IR}) \\
92(\$)\end{array}$ & $1,014,794$ (IR) 64 (\$) & $\begin{array}{l}828,864(\mathrm{IR}) \\
53(\$)\end{array}$ & $\begin{array}{l}4,172,504(\mathrm{IR}) \\
265(\$)\end{array}$ & $\begin{array}{l}2,926,280(\mathrm{IR}) \\
186 \mathbf{( \$ )}\end{array}$ \\
\hline $\begin{array}{l}\text { Drugs and } \\
\text { supplies }\end{array}$ & 28 & $\begin{array}{l}8,044,070,257(\mathrm{IR}) \\
510,209(\$)\end{array}$ & $\begin{array}{l}16,863,879(\mathrm{IR}) \\
1070(\$)\end{array}$ & $\begin{array}{l}30,468,242(\mathrm{IR}) \\
1933(\$)\end{array}$ & $\begin{array}{l}12,396,651(\mathrm{IR}) 786 \\
(\$)\end{array}$ & $\begin{array}{l}17,803,503(\mathrm{IR}) \\
1129(\$)\end{array}$ & $\begin{array}{l}71,587,424(\mathrm{IR}) \\
4541(\$)\end{array}$ & $\begin{array}{l}68,004,175 \text { (IR) } \\
4313 \text { (\$) }\end{array}$ \\
\hline $\begin{array}{l}\text { Rehabilitation } \\
\text { and Dialysis }\end{array}$ & 1 & $\begin{array}{l}358,674,154(\mathrm{IR}) 22 \\
750(\$)\end{array}$ & $\begin{array}{l}751,937(\mathrm{IR}) \\
48(\$)\end{array}$ & $\begin{array}{l}2,897,736(\mathrm{IR}) \\
184(\$)\end{array}$ & $373,737(\mathrm{IR}) 23(\$)$ & $\begin{array}{l}1,587,375(\mathrm{IR}) \\
101(\$)\end{array}$ & $\begin{array}{l}5,384,891(\mathrm{IR}) \\
342(\$)\end{array}$ & $\begin{array}{l}7,226,606(\mathrm{IR}) \\
458(\mathbf{\$})\end{array}$ \\
\hline Imaging & 2 & $\begin{array}{l}704,609,641 \text { (IR) 44, } \\
691(\$)\end{array}$ & $\begin{array}{l}1,477,169(\mathrm{IR}) \\
94(\$)\end{array}$ & $\begin{array}{l}1,191,832(\mathrm{IR}) \\
76(\$)\end{array}$ & 1,368,356(IR) $87(\$)$ & $\begin{array}{l}1,045,763(\mathrm{IR}) \\
66(\$)\end{array}$ & $\begin{array}{l}2,810,123(\mathrm{IR}) \\
178(\$)\end{array}$ & $\begin{array}{l}1,786,642(\mathrm{IR}) \\
113(\$)\end{array}$ \\
\hline $\begin{array}{l}\text { Electrography } \\
\text { and Laboratory }\end{array}$ & 9 & $\begin{array}{l}2,645,752,049(\mathrm{IR}) \\
167,811(\$)\end{array}$ & $\begin{array}{l}5,546,650(\mathrm{IR}) \\
352(\$)\end{array}$ & $\begin{array}{l}5,263,980(\mathrm{IR}) \\
334(\$)\end{array}$ & $\begin{array}{l}4,729,388 \text { (IR) } 300 \\
(\$)\end{array}$ & $\begin{array}{l}3,672,308(\mathrm{IR}) \\
233(\$)\end{array}$ & $\begin{array}{l}15,558,103(\mathrm{IR}) \\
987(\$)\end{array}$ & $\begin{array}{l}9,015,815(\mathrm{IR}) \\
572(\$)\end{array}$ \\
\hline Other services & 1 & $\begin{array}{l}325,476,558 \text { (IR) 20, } \\
644(\$)\end{array}$ & $\begin{array}{l}682,341(\mathrm{IR}) \\
43(\$)\end{array}$ & $\begin{array}{l}459,965(\mathrm{IR}) \\
29(\$)\end{array}$ & $635,339(\mathrm{IR}) 40$ (\$) & $\begin{array}{l}383,438(\mathrm{IR}) \\
24(\$)\end{array}$ & $\begin{array}{l}1,258,107(\mathrm{IR}) \\
80(\$)\end{array}$ & 781,671 (IR) 50 \\
\hline Total & 100 & $\begin{array}{l}28,240,025,968 \\
\text { (IR) } 1,791,172 \text { (\$) }\end{array}$ & $\begin{array}{l}59,203,409 \\
\text { (IR) } 3755 \text { (\$) }\end{array}$ & $\begin{array}{l}73,855,161 \\
\text { (IR) } 4684 \text { (\$) }\end{array}$ & $\begin{array}{l}46,961,630 \text { (IR) } \\
2979 \text { (\$) }\end{array}$ & $\begin{array}{l}41,459,732 \\
\text { (IR) } 2630 \text { (\$) }\end{array}$ & $\begin{array}{l}209,165,200 \\
\text { (IR) } 13,267(\$)\end{array}$ & $\begin{array}{l}151,535,892 \\
\text { (IR) } 9611 \text { (\$) }\end{array}$ \\
\hline \multicolumn{3}{|l|}{ Indirect Cost } & \multicolumn{6}{|c|}{ Mean cost per patient } \\
\hline \multicolumn{3}{|c|}{ Lost income (hospitalization) } & \multicolumn{6}{|c|}{ 5,950,524 (IR) 378 (\$) } \\
\hline \multicolumn{3}{|c|}{ Lost income (recovery at home) } & \multicolumn{6}{|c|}{ 16,800,000 (IR) 1065 (\$) } \\
\hline \multicolumn{3}{|c|}{ Potential productivity Loss (premature death) } & \multicolumn{6}{|c|}{ 107,107,949 (IR) 10,190 (\$) } \\
\hline \multicolumn{3}{|l|}{ Total } & \multicolumn{6}{|c|}{ 129,870,974 (IR) 11,634 (\$) } \\
\hline
\end{tabular}

the United States have been causing concerns among the managers and policy-makers in the health sector. Hence, identifying the economic consequences of COVID-19 can be valuable evidence for policy-making.

The average direct medical costs for these patients were estimated to be $\$ 3755$ per person. Based on a recent study in the United States conducted by Bartsch et al., the average direct medical costs per person were estimated to be $\$ 3045$ throughout the infection [15]. In this regard, the results of these two studies are comparable. The results of this study also showed that this record of information varied with the severity of the disease. Critically-ill patients who received ICU services accounted for the largest share of direct medical costs. Although nearly $7 \%$ of the patients with COVID-19 had received ICU services, they accounted for almost $26 \%$ $(7,529,947,215$ rials $/ \$ 477,600)$ of the total direct medical costs. Indeed, on average, patient care in intensive care units was four times more expensive than other patients.

The spread of the disease caused not only direct costs but also many indirect ones, including the potential production loss due to job absenteeism during hospitalization and recovery course at home, as well as production loss due to premature death. The productivity loss of the patients with COVID-19 was about two times more than the direct medical costs per patient on average.

According to the findings of this study, the mean direct and indirect costs in total certainly for inpatient cases was 43,173,908,604,828 Rials so far, which was accounting for $1.5 \%$ of the average annual health expenditures in 2018. Public hospitals in Iran's health system are funded through two primary sources including the Social Security Organisation (IHIO) reimbursement based on fee-for-service (FFS) and perdiem payments or the government budget by the Ministry of Health and Medical Education (MoHME) [37]. Furthermore, patients need to pay $10 \%$ of expenses for hospital services [38]. This also is applying to care and services in the case of COVID-19. Nonetheless, in order to determine whether this condition may impose catastrophic costs on patients and their families, more studies are needed to examine the issue through considering household incomes and expenses and patients' capacity to pay for treatment.

Recent experiences have shown that in the absence of an effective treatment or vaccine, limiting the working hours and activities of small businesses or promoting 
telecommuting in the context of social distancing have been used as the main measures related to the control and prevention of COVID-19.

Although the resulting recession could pose additional economic challenges to government funding for these jobs, given the contagious nature of the disease, the epidemic, and the high prevalence rates _that can lead to disruption in routine health care as well as specific care provision for COVID-19_ and also with respect to the results of this study based on the high costs of this disease for various sectors including the health system, investing in creating distance working possibilities and considering livelihood support packages as incentives that people are determined to follow the protocols, can be offset by reduction in the financial burden of the disease, including the financial burden of premature death and reducing treatment costs.

\section{Research limitations and suggestions for future studies}

Due to the limited access to socioeconomic information of the participants in this study, complementary investigation of the work productivity loss by the individuals' income deciles was not carried out. Another research limitation was the unprecedented circumstances during the COVID-19, which avoid researchers conducting an in-depth investigation of indirect cost through an interview with patients and nonmedical direct cost estimation such as travel expenses save for productivity loss. Therefore, considering the mentioned issues suggested in future studies.

\section{Conclusion}

Examining the economic dimensions of the disease through this research provided significant evidence for making socioeconomic policies related to COVID-19 and similar epidemics. According to the results of this study, the high rate of pathogenicity, a considerable percentage of patients in need of intensive care and subsequently the enormous costs of the disease (direct and indirect) can face the country's health system with unprecedented and significant economic stress in financing government and university medical centres. Thus, these centres might be forced to apply painful cost-control and rationing policies in providing the necessary care to this group of patients and others.

\section{Abbreviations}

COVID-19: Corona Virus Disease 2019; DC: Direct Cost; FLO: The Forgone Labor Output; GDP: Gross Domestic Product; IC: Indirect Cost; ICU: Intensive Care Unit; PPP: Purchasing Power Parity; WHO: World Health Organization

\section{Acknowledgements}

Not applicable.

\section{Authors' contributions}

KK and ZK conceptualized and designed the study. ES and JS Collected the data and helped to draft the manuscript. MG and KK analyzed and interpreted the data and finalized the manuscript. All authors have read and approved the manuscript.

\section{Funding}

This research received no specific grant from any funding agency, commercial or not-for-profit sectors.

\section{Availability of data and materials}

The datasets used and analyzed during the current study are available from the corresponding author on reasonable request.

\section{Ethics approval and consent to participate}

Ethics approval related to the research circumstances was obtained from the ethical committee of Shiraz University of Medical Sciences (approval no. IR.SUMS.MED.REC.1399: 99-01-106-22298). However, due to the nature of this study, it was exempt from consent to participant given that the study was a non-interventional retrospective one using a data in which patient identification information had been removed.

\section{Consent for publication}

Not applicable.

\section{Competing interests}

The authors declare that they have no competing interests.

\section{Author details}

${ }^{1}$ School of Management and Medical Informatics, Shiraz University of Medical Sciences, Shiraz, Iran. ${ }^{2}$ Health Human Resources Research Centre, School of Management and Medical Informatics, Shiraz University of Medical Sciences, Shiraz, Iran. ${ }^{3}$ Student Research Committee, School of Management and Medical Informatics, Shiraz University of Medical Sciences, Shiraz, Iran. ${ }^{4}$ Student Research Committee, Shiraz University of Medical Sciences, Shiraz, Iran.

Received: 20 September 2020 Accepted: 27 January 2021

Published online: 11 February 2021

\section{References}

1. Lu H, Stratton CW, Tang YW. Outbreak of pneumonia of unknown etiology in Wuhan, China: The mystery and the miracle. J Med Virol. 2020;92(4):4012. https://doi.org/10.1002/jmv.25678.

2. Zhu N, Zhang D, Wang W, Li X, Yang B, Song J, et al. China Novel Coronavirus Investigating and Research Team. A Novel Coronavirus from Patients with Pneumonia in China, 2019. N Engl J Med. 2020;382(8):727-33. https://doi.org/10.1056/NEJMoa2001017.

3. Coronavirus disease (COVID-19) Pandemic - Emergency Use Listing Procedure (EUL) open for in vitro diagnostics: World Health Organisation; 2020 [cited 2020 cited4/17/2020]. Available from: https://www.who.int/ diagnostics_laboratory/EUL/en/.

4. Coronavirus disease 2019 (COVID-19). situation report; 2020. p. 72.

5. worldometer. [Internet]. 2020 [cited 04/06/2020]. Available from: www. worldometers.info/coronavirus.

6. Sabino-Silva R, Jardim ACG, Siqueira WL. Coronavirus COVID-19 impacts to dentistry and potential salivary diagnosis. Clin Oral Investig. 2020;24(4):161921. https://doi.org/10.1007/s00784-020-03248-X.

7. Chen N, Zhou M, Dong X, Qu J, Gong F, Han Y, et al. Epidemiological and clinical characteristics of 99 cases of 2019 novel coronavirus pneumonia in Wuhan, China: a descriptive study. Lancet. 2020;395(10223):507-13.

8. Wu Z, McGoogan JM. Characteristics of and important lessons from the coronavirus disease 2019 (COVID-19) outbreak in China: summary of a report of 72314 cases from the Chinese Center for Disease Control and Prevention. Jama. 2020.

9. Zhou F, Yu T, Du R, Fan G, Liu Y, Liu Z, et al. Clinical course and risk factors for mortality of adult inpatients with COVID-19 in Wuhan, China: a retrospective cohort study. Lancet. 2020;395(10229):1054-62. https://doi.org/ 10.1016/S0140-6736(20)30566-3.

10. World Health Organization. [Internet]. 2020 [cited6/28/2020]. Available from: https://www.who.int/news-room/detail/11-05-2020-the-cost-of-inactioncovid-19-related-service-disruptions-could-cause-hundreds-of-thousands-ofextra-deaths-from-hiv. 
11. Hogan AB, Jewell BL, Sherrard-Smith $E$, et al. Potential impact of the COVID19 pandemic on HIV, tuberculosis, and malaria in low-income and middleincome countries: a modelling study. The Lancet Global Health. 2020; 8: e1132-e41. https://doi.org/10.1016/S2214-109X(20)30288-6.

12. Gupta AG, Moyer CA, Stern DT. The economic impact of quarantine: SARS in Toronto as a case study. J Infect. 2005;50(5):386-93.

13. Warren DK, Shukla SJ, Olsen MA, Kollef MH, Hollenbeak CS, Cox MJ, et al. Outcome and attributable cost of ventilator-associated pneumonia among intensive care unit patients in a suburban medical center. Crit Care Med. 2003;31(5):1312-7.

14. Cheung AM, Tansey CM, Tomlinson G, Diaz-Granados N, Matté A, Barr A, et al. Two-year outcomes, health care use, and costs of survivors of acute respiratory distress syndrome. Am J Respir Crit Care Med. 2006;174(5):53844.

15. Bartsch SM, Ferguson MC, McKinnell JA, O'Shea KJ, Wedlock PT, Siegmund SS, et al. The Potential Health Care Costs And Resource Use Associated With COVID-19 In The United States. Health Aff (Millwood). 2020;39(6):927-35. https://doi.org/10.1377/hlthaff.2020.00426.

16. Rapoport J, Teres D, Zhao Y, Lemeshow S. Length of stay data as a guide to hospital economic performance for ICU patients. Med Care. 2003;41(3):38697. https://doi.org/10.1097/01.MLR.0000053021.93198.96.

17. Dasta JF, McLaughlin TP, Mody SH, Piech CT. Daily cost of an intensive care unit day: the contribution of mechanical ventilation. Crit Care Med. 2005; 33(6):1266-71.

18. Norris C, Jacobs P, Rapoport J, Hamilton S. ICU and non-ICU cost per day. Can J Anaesth. 1995;42(3):192-6.

19. Wang D, Hu B, Hu C, Zhu F, Liu X, Zhang J, et al. Clinical characteristics of 138 hospitalized patients with 2019 novel coronavirus-infected pneumonia in Wuhan, China. Jama. 2020;323(11):1061-9.

20. Grasselli G, Zangrillo A, Zanella A, Antonelli M, Cabrini L, Castelli A, et al. COVID-19 Lombardy ICU Network. Baseline Characteristics and Outcomes of 1591 Patients Infected With SARS-CoV-2 Admitted to ICUs of the Lombardy Region, Italy. JAMA. 2020;323(16):1574-81. https://doi.org/10.1001/jama.2020. 5394.

21. Oostenbrink JB, Buijs-Van der Woude T, van Agthoven M, Koopmanschap MA, Rutten FF. Unit costs of inpatient hospital days. Pharmacoeconomics. 2003;21(4):263-71.

22. Lee J-W, McKibbin WJ. Estimating the global economic costs of SARS. Learning from SARS: preparing for the next disease outbreak: workshop summary. Washington, DC: National Academies Press; 2004.

23. Rice DP, Hodgson TA, Kopstein AN. The economic costs of illness: a replication and update. Health Care Financing Rev. 1985;7(1):61.

24. Brahmbhatt M, Dutta A. On SARS type economic effects during infectious disease outbreaks: the World Bank; 2008.

25. Keogh-Brown MR, Smith RD, Edmunds JW, Beutels P. The macroeconomic impact of pandemic influenza: estimates from models of the United Kingdom, France, Belgium and the Netherlands. Eur J Health Econ. 2010; 11(6):543-54.

26. Mckibbin W, Fernando R. The economic impact of COVID-19. Economics in the Time of COVID-19; 2020. p. 45.

27. Fernandes N. Economic effects of coronavirus outbreak (COVID-19) on the world economy. Available at SSRN 3557504; 2020.

28. Kabir M, Afzal MS, Khan A, Ahmed H. COVID-19 pandemic and economic cost; impact on forcibly displaced people. Travel Med Infect Dis. 2020;35: 101661. https://doi.org/10.1016/j.tmaid.2020.101661.

29. Mental Health Economics: The Costs and Benefits of Psychiatric Care: Springer International Publishing; 20172017.

30. Daroudi AZK, Nahvijou A, Zahmatkesh AA. A Review of Methods for Estimating Economic Burden of Cancer. Hakim Health Syst Res J. 2014;16(4): 349-57.

31. Tarricone R. Cost-of-illness analysis: what room in health economics? Health Policy. 2006;77(1):51-63.

32. Hartunian NS, Smart CN, Thompson MS. The incidence and economic costs of cancer, motor vehicle injuries, coronary heart disease, and stroke: a comparative analysis. Am J Public Health. 1980;70(12):1249-60.

33. Rice DP. Cost-of-illness studies: fact or fiction? Lancet. 1994;344:1519-20.

34. The Cost of Air Pollution. Strengthening the Economic Case for Action. Washington, DC. (c) World Bank: Institute for Health Metrics and Evaluation: World Bank; 2016.

35. Keshavarz K, Kebriaeezadeh A, Alavian SM, Sari AA, Dorkoosh FA, Keshvari M, et al. Economic burden of hepatitis B virus-related diseases: evidence from iran. Hepat Mon. 2015;15(4):e25854. https://doi.org/10.5812/hepatmon. 15(4)2015.25854.

36. Islamic Republic of Iran Implied PPP Conversion Rate, LCU per USD 2020 [7/ 27/2020]. Available from: https://www.quandl.com/data/ODA/IRN_PPPEXIslamic-Republic-of-Iran-Implied-PPP-Conversion-Rate-LCU-per-USD.

37. Bazyar M, Rashidian A, Alipouri Sakha M, Vaez Mahdavi MR, Doshmangir L. Combining health insurance funds in a fragmented context: what kind of challenges should be considered? BMC Health Serv Res. 2020;20(1):26.

38. Doshmangir L, Rashidian A, Kouhi F, Gordeev VS. Setting health care services tariffs in Iran: half a century quest for a window of opportunity. Int J Equity Health. 2020;19(1):112.

\section{Publisher's Note}

Springer Nature remains neutral with regard to jurisdictional claims in published maps and institutional affiliations.
Ready to submit your research? Choose BMC and benefit from:

- fast, convenient online submission

- thorough peer review by experienced researchers in your field

- rapid publication on acceptance

- support for research data, including large and complex data types

- gold Open Access which fosters wider collaboration and increased citations

- maximum visibility for your research: over $100 \mathrm{M}$ website views per year

At BMC, research is always in progress.

Learn more biomedcentral.com/submissions 